\title{
Psychological Description of Investigative (Search) Actions
}

\author{
Yuliia Chornous 1 [0000-0001-9710-4858], Valentyna Drozd 2 [0000-0002-7687-7138], \\ Liudmyla Havryliuk $2 *$ [0000-0002-9441-4073]
}

\author{
${ }^{1}$ National Academy of Internal Affairs, Kyiv, Ukraine \\ ${ }^{2}$ State Research Institute of the Ministry of Internal Affairs of Ukraine, Kyiv, Ukraine \\ *Lvg4323@ukr.net
}

\begin{abstract}
The scientific literature highlights various aspects of investigative (search) actions, but this study focuses on their psychological description, which currently has not been developed sufficiently. The study of the psychological description of investigative (search) actions contributes to revealing their essence and to identifying the psychological processes in the course of forensically relevant information handling. Accordingly, the development of criminological recommendations, which consider psychological data, contributes to the effective implementation of the objectives of criminal proceedings. From the operational perspective, the psychological description of investigative (search) actions is revealed through cognitive, constructive, communicative, organizational and verifying components. The psychological description of investigative (search) actions is affected by the problematic situations that arise in the investigative activity. The key ones are: the lack of time and the need to act within the established investigation time frame; the urgency of some investigative (search) actions; the negative emotions as a result of the need to communicate with unscrupulous participants in criminal proceedings; the need to apply a range of measures to overcome resistance against investigations; the conflicts and the difficulty of resolving them; an inadequate level of logistics and the need to improve the organization of activities; a decline in the authority and credibility of law enforcement personnel; a negative attitude of citizens towards assistance and cooperation with law enforcement bodies, etc. The psychological description of investigative (search) actions provides for general objective psychological regularities and takes into account individual specificities expressed in the course of practical activities of investigative and other competent actors.
\end{abstract}

Keywords: investigative (search) actions, investigation, psychological description, psychological impact, investigator

\section{INTRODUCTION}

The investigation of criminal offences require lawful, tactically correct and effective investigative (search) actions, subordinate to the objectives of criminal proceedings, in order to ensure prompt, full and impartial investigation and court consideration of criminal proceedings with a view to upholding the principle of legality.

The concept of investigative (search) actions is developed in science and practice and is comprehensive, since it can be characterized from criminal procedural, organizational and tactical, moral and psychological perspectives. Considering the comprehensiveness and inadequacy of its study from the psychological perspective, we will focus on this issue.

It should be noted that the concept of investigative (search) actions has been studied in monographs by V.S. Kuzmichov, Yu.M. Chornous [1], S.Yu. Karpushyn [2]. However, currently the literature review has revealed that this issue has not been studied from the perspective of the psychological sciences, which requires theoretical processing of its scientific provisions and recommendations for practitioners, such as inquiry officers, investigators, detectives, prosecutors, judges, lawyers, aimed at applying psychological knowledge to their law application activities. 


\section{METHODOLOGY}

The aim of the scientific article is to highlight the psychological description of investigative (search) actions. In the course of the study, different methods of scientific knowledge are used [3-5]. In particular, comparative legal one is applied to the analysis of the provisions of Ukrainian legislation, scientific concepts, definitions and approaches; historical and legal one enables to reveal the content of the concepts of "investigative actions," "psychological description," to highlight the development of scientific perspectives on individual problematic issues; systematic analysis enables to comprehensively review practical experience in the conduct of investigative (search) actions in the investigation of criminal offences; the systemic and structural method enables to identify features of psychological processes in the investigator's performance.

\section{RESULTS}

The means, methods and techniques used in the investigation of criminal offences are extremely varied and can be conditionally grouped into procedural and non-procedural. Procedural means, that is, investigative (search) actions, are essential in ensuring the process of proof in criminal proceedings.

The concept of investigative actions has long been known in criminal proceedings, developed in the works by scientists in the field of criminal procedure and forensic science. At the same time, legal scholars underline the importance of involving psychological knowledge in order to improve theoretical knowledge and effectively attract practical forensic tools.

The interaction of criminology with other sciences enables to adapt the methods of the latter to the investigation and court consideration of criminal offences through the study of how to apply their achievements in practice.

Using natural and humanistic knowledge, forensics has become a kind of encyclopaedia used to achieve the purpose and objectives of criminal proceedings, and the volume of this encyclopaedia is constantly increasing [6, pp. 36-37, 7-9].

Therefore, the efficiency of the pre-trial investigation requires involving data and achievements of psychology. The sciences, such as criminal procedure, criminalistics and psychology, constantly interact with each other in order to perform common tasks in various investigative situations. Moreover, the investigative (search) actions can be described in relation to cognitive and operational aspects from the perspective of psychology. Let us focus on this issue.

\section{DISCUSSION OF THE RESULTS}

The psychological description of investigative (search) actions is determined by the impact of psychology on the content of investigative activities as an individual type of human activity.

The scientists of various fields of knowledge focus on interpretation of the concept "activity," because it acts as the existence of social. In a broad meaning, the concept of "activity" refers to various ways human beings apply to explore the world, the form of combat that characterizes the ability of human beings or related systems to be the cause of changes in existence, a form of active human attitude to the world in order to transform it. The main feature of the activity is its awareness, it includes the purpose, the means, the result and the form of the activity itself.

The concept of "activity" is considered according to several meanings: 1) a combination of results and consequences, that is, products, achievements, etc. 2) a synonym with "work"; 3) work on oneself, human selfdevelopment; 4) practical solution of tasks (activity as practice).

An action-oriented approach leads in the study of investigative (search) actions and the psychological processes they involve.

The study of the concepts of "investigative activity" and "activities related to the conduct of investigative (search) actions" enable to conclude that the first concept covers the application of the set of procedural actions and non-procedural measures that in practice are a dynamic, structurally complex phenomenon, carried out in accordance with the provisions of the criminal procedure legislation and aimed at achieving its objectives. Moreover, investigative (search) actions are a central, key element of these activities, which are directly linked to ensuring the process of proof and establishing the truth.

The investigation of crimes is the knowledge of the past events from the tangible and ideal traces remained. Two main features are connected to this: first, the lack of direct perception of something that should become known, and second, the influence of objective and subjective factors on the traces of the event that should become known. In its form and content, investigation is a complex dynamic system, the main function thereof is to effectively counter criminal activity, though a number of factors become obstacles, such as: interference with obtaining complete and objective information by the persons concerned, difficulties in properly decoding the information received, etc. The investigation takes place in a difficult psychological environment as a result of the quite frequent conflicts of interest of the persons involved [10]. 
The reasons for resistance with the investigation are manifold. These include strong emotional tension of the defendant, apathy, a negative attitude towards the investigator or the investigation process, a desire to avoid criminal liability for the criminal offence committed, etc. Resistance may take the form of special actions (activities) aimed at concealing the event and traces of the crime, their staging and falsification, including the development and creation of various combinations, legends, alibis, that is, persons concerned perform not one, but a whole range of actions [11].

Resistance may be exercised both at the preparatory stage and during or after the commission of a criminal offence. Often, resistance in general or in individual cases is closely related to a criminal offence and is an autonomous criminal activity. This circumstance contributes to a special, psychological tension in investigative actions, which affects their tactics.

The importance of the study on psychological description of the investigation (search) actions is due to a number of factors.

Therefore, the task of psychology in forensic tactics is aimed at developing tactical techniques for achieving a number of objectives. For example, a technique, identified in forensic tactics as the key element of investigative (search) action tactics, is psychological, due to the psychological mechanism of its implementation.

A significant feature of investigative (search) actions is their educational orientation.

B.O. Konovalova (Konovalova, V.E, 1973, p. 38) argues that the essence of investigative activity is the knowledge that is implemented in a separate branch. All the investigator's activities, related to the investigation of the crime, are subordinated to the establishment of objective truth in the case, that is, the knowledge of the specific [12, p. 38]. The knowledge of the investigator and the proof are dialectically united, and the proof in criminal proceedings is a procedural form of knowledge of the facts of criminal proceedings [13].

In addition to the key and cognitive components, the investigator's activity consists of constructive, communicative, organizational and verifying components aimed at learning the event of a criminal offence.

For example, constructive activities consist of identifying, organizing and systematizing forensic information collected. On the basis of this performance, useful investigative (search) actions are selected, and the order of their conduct is determined, as well as a plan for their conduct (oral or written) is outlined.

In this context, the constructive activity is closely related to the prognostic one and involves foreseeing, with the greatest possible degree of reliability, the state of the object or characteristics of its development at a given time or period in the future.

Communication activities are important in order to create a working environment, establish and maintain psychological contact with participants in criminal proceedings and ensure effective cooperation.

Organizational activities involve a set of measures, which may be both of procedural and of subsidiary, ensuring nature, that are an enabling environment for the investigation (search) action.

The verifying activities provide information obtained as a result of the investigative (search) action with due procedural form. This process refers to transferring ideal information, perceived by the investigator in law application activities, into materially fixed information. This requires maximum reliability, objectivity and accuracy of the information displayed.

As a result of these and a number of other psychological operations during the pre-trial investigation by the investigator, evidence is obtained and the facts of the criminal offence are established, similar to a transition of the sensual perception of individual facts, features and qualities of one or the other objects in different fields of human activities to the logical grounds of perceived and rational thinking.

The investigator's application of the techniques of logical thinking (analysis, synthesis, induction, deduction, analogy, other categories of logic) and the methods of observation, measurement, description, comparison, experiment, psychic processes of sensation, perception, memory, apprehension, thinking, emotions, willpower are expressed in the form of practical actions in the course of forensically relevant information handling. From the psychological perspective, this manner of obtaining information is a form of reflection and is expressed as a sensual knowledge, that is, perception of the traces of the event under analysis, during which they are detected and studied, identified according to features reflecting the influence of the event under investigation, constructed into a cognitive image, which is comprehended, then information received is evaluated in order to determine areas and ways of its further use.

The specificity of each investigative (search) action is determined by the cognitive, constructive, communicative, organizational and verifying operations that constitute its content, their ratio and the tasks to be performed. Their combination depends on many factors, including the affiliation of the investigative (search) action with a group of verbal, non-verbal or complex (mixed) elements. That is, depending on which object the investigator interacts with: "man," "things," "manthings," various psychological mechanisms are used in the activities of the investigator, and this fact impacts on the tactics of the investigation (search) action. 
The content of these psychological mechanisms can be revealed by rules and techniques of communication as a process of information exchange, dialogue between the investigator and persons, who are carriers of ideal traces, in the course of interrogation, simultaneous interview of two or more persons who have already been interviewed, an investigative experiment, etc. The investigator analyses both spoken (verbal) and non-verbal (gestures, facial expressions) information and their combination. As a result of verbal investigative (search) actions, evidence is obtained in verbal (oral) form. This is the testimony of the suspect, victim, witness. The ideal traces usually materialize in the course of communication between participants in criminal proceedings, using verbal and non-verbal means. In this context, the records of verbal investigative (search) actions constitute the materialized fixation of memory traces. It is in this way that they are made available to an outside observer and used in proving. In this context, ideal traces are fundamentally different from tangible traces by the manner of identification, recording, research, where specific methods and means of their processing are applied.

Despite its subjective nature, the mental image is sufficiently comprehensive and adequate to reflect objective reality and can be successfully used for forensic purposes: to find media, to establish data of interest to the investigator, to identify, to establish and search a person, etc.

Therefore, the ideal trace has an objective meaning, because it reflects an objective reality, and a subjective form, as it is reflected in the consciousness of a particular person. Instead, perception depends on many personal, psychological, physical qualities and states, and therefore, has a subjective-objective character.

Identification of the nature of ideal traces should be based on the fact that the ideal traces in forensics are not only the result of a reflection of reality in the mind of a particular person, but also the form of preservation (reflection) of relevant information.

Ideal traces exist objectively in a person's memory, and the amount of information that is stored in ideal traces is usually larger than the amount of information obtained (recovered) from these traces. The investigator's duty is to update (restore, renovate, rebuild, retrieve, revitalize, receive, obtain, regain) information from these traces. This can be considered to have been accomplished when the amount of information stored and obtained is almost identical [14, p. 60].

The study on the psychological mechanism of creating ideal traces should consider the absence of direct contact between the actors involved. The ideal image is reflected in the form of consciousness, and the object in which the images are preserved is the human being.
Ideal information, processed in the human mind in connection with the event of a criminal offence, is varied. By its physical nature it can be visual, auditory, gustatory, tactile, olfactory, spatiotemporal. By the level of perception, this information can be obvious and covert. By the procedural status of the person, who perceived and provides this information, it can be from the victim, a witness, a specialist, an expert, a suspect or another person. By the form of expression, this information can be verbal, graphical, symbolic, etc. This classification can be continued, but an individual approach to handling ideal information and a specific approach to the choice of processing methods should be underlined.

Moreover, the psychological description of the investigative (search) action depends on the actor whose ideal information is the subject of the study. For example, it is most informative from persons who have directly perceived the event of a criminal offence or who are the perpetrators. Objective information is received from persons who have indirectly perceived the event of a criminal offence and have competently performed certain tasks during the criminal proceedings (witnesses, specialists). It should be considered that in all circumstances, information may be objective and reliable, as well as unreliable (totally or in part) due to objective and subjective circumstances.

In the course of investigative (search) actions, the investigator performs complex psychological tasks in order to clarify the facts of the criminal proceedings, and reflexive thinking is an important technique in these circumstances. Its specificity is the mental coverage of the entire mechanism of the committed criminal offence, the analysis of trace information, the simulation of the actions of the alleged offender, of the purpose and motives of his/her activity, on the basis of which the investigator selects the most tactically appropriate course of conduct during the pre-trial investigation.

The investigator conducts investigative (search) actions in compliance with the laws of logical thinking. However, in case of unforeseen situations, the investigator has to rely on intuition as a sudden solution without a full logical explanation in order to achieve the objectives. In the investigator's thinking, logic and intuition often interact or operate in a sequence where one of the ways makes, prepares the entry into force of the other. Logic permeates intuition, locates in it in a folded form, while intuition complements logical thinking [12, pp. 82-87].

The psychological description of investigative (search) actions is closely related to other characteristics. For example, the legal and regulatory mechanism is the most vivid psychological feature of the investigator's performance, which requires strict observance of procedural rules, allowing for the freedom to choose the means and methods within their limits [12, p. 39]. The psychological features of the investigator's activity 
include powers, which, from psychological perspective, are the phenomenon, on the one hand, of legal sufficiency and, on the other hand, of the confidence of citizens in the personnel of investigative bodies [15, p.119-120].

Furthermore, the relationship between the psychological description of investigative (search) actions is revealed in the aspect of citizens' rights and freedoms. V. S. Medvediev (Medvediev, V.S., 2000) argues that the rights of citizens can be considered in the social, legal and psychological aspects. However, the psychological aspect derives from the subjective perception by individual citizens or their groups of their rights, their rational and emotional evaluation, conscious or volitional application [15, pp. 119-120].

A state of heightened responsibility for timely and lawful actions and decisions causes a special psychological state in the mind of the investigator, which is reflected in the implementation of the tasks in criminal proceedings.

The psychological description of investigative activity is affected by various problematic situations, such as: 1) the lack of time and the need to act within the established time frame for investigation; 2) the urgency of a number of investigative (search) actions; 3 ) negative emotions as a result of the need to communicate with unscrupulous participants in criminal proceedings; 4) the need to apply a range of measures to overcome resistance against the investigation; 5) conflicts and the difficulty of resolving them.

Certain circumstances negatively affect the personality of the investigator and his/her psychological state that may contribute to low efficiency of his/her performance. Such adverse factors include external, objective circumstances: 1) inadequate level of logistical support; 2) deficiencies in the organization of pre-trial investigation bodies; 3) reduction of authority and credibility of law enforcement officials and the negative attitude of citizens towards assistance and cooperation with law enforcement officials.

Furthermore, the focus should be on internal, subjective personal factors, such as: 1) the lack of necessary knowledge and skills; 2) insufficient practical experience; 3) professional incompetence; 4) personal problems; 5) low self-esteem. The investigator may experience negative psychological processes and stress. The long-term effects of negative psychological processes can lead to psychological deformation.

The psychological effectiveness of the investigator is enhanced by the development of his or her mental cognitive processes and motivation, as well as by the understanding and solution of problems related to his or her professional interests. A positive effect has the investigator's sense of professional interest, creativity, inspiration and self-confidence.
Another feature that affects the psychological description of investigative (search) actions is the conflicting nature and resistance of individual participants in criminal proceedings. The conflicting nature may express in various forms: first, the investigator's internal personal conflict related to the insufficient and contradictory evidentiary information, negative attitudes towards certain participants in criminal proceedings, etc. Second, a conflict may arise as a result of the updated psychological relations between the parties to the conflict, who have opposing target orientations.

The resistance of persons concerned largely determines the specificities of searching and collecting evidence in the course of investigative (search) actions. To overcome it, a set of targeted, planned and coordinated actions is required to compensate for or neutralize the disabling environment for or interference with knowledge. Psychological impact is a common and effective technique of overcoming the resistance of the persons concerned.

Psychological impact is objectively inherent in investigative activities, prevention of criminal offences and court consideration of criminal cases. Practically it is expressed in the implementation of tactics in the course of achieving the objectives of criminal proceedings. Under these conditions, the application of tactical techniques requires thorough training of the investigator, prosecutor, judge, and others, including verification of their conformity with legal and moral standards; assessment of possible tactical risk and its justification; forecasting of participants' behaviour; identification of measures in case of emergency and situation spiralling out of control; application of the results obtained.

The psychological mechanism for the implementation of the tactical technique consists of:

- Direct or indirect interaction between the person conducting the criminal proceeding and respondents;

- Its psychological orientation related to reproducing the event, updating the forgotten, revealing lies and finding the hidden;

- The psychological effect of the tactical technique (related to the need to obtain truthful testimony and to detect evidence of a criminal offence).

Inherently, every tactical technique has psychological effect. In turn, psychological effect in criminal proceedings is exercised through the tactical technique or their sets. That is, psychological impact, provided that the criteria of admissibility are met, characterizes investigative activities, prevention of criminal offences and court consideration [16].

Moreover, the process of psychological impact involves several stages: the psychological diagnosis of the individual; the choice of the sequence of 
psychological measures, which is determined through planning and reflexive management; application of psychological impact; evaluation of psychological effects; evaluation of the evidential value of the information received [12, p. 107].

For example, a conflict-free environment requires appropriate psychological techniques such as: communication of information (providing psychological assistance by reminding, activating thinking and memory in order to restore and reproduce previously perceived facts); stimulation of positive qualities of a person; involvement of a person in cooperation through activation of his/her emotions and feelings; promotion of recollection of forgotten facts by the participants through associations of similarities, contiguity, opposition, paraphrasing, disconnection, visual viewing; restoration of associative ties; reproduction of the circumstances of perception; removal of attention dissemination by focusing it; activation of attitudes in the emotional and volitional sphere.

In a conflict context, the application of the method of communication of information is interfered with the resistance of the participant, so the investigator's activity is primarily directed towards overcoming his/her negative attitude.

In a conflict context, the method of information communication requires tactical techniques of conversation, free narrative with further detail of the evidence, the use of positive qualities of the participant; the "blank" effect; legend; surprise; sequence; distraction (disguising the purpose of the investigative (search) action); exaggerated impression on the investigator's knowledge or, conversely, the investigator's ignorance, etc.

Psychological impact in investigative (search) actions is appropriate because it meets the nature of investigative activities, but subject to the provisions of the law against deceit or falsification, disgrace of human dignity and restriction of legitimate rights. Failure to use psychological techniques by the investigator will prevent him/her from creatively addressing the objectives of the pre-trial investigation and will limit his/her activity to the performance of technical functions. Prevention from the use of psychological techniques against unscrupulous participants would disarm the investigator, completely deprive him/her of the means to overcome the resistance, especially now, in an era of rising crime and declining morals.

The procedure for certain investigative (search) actions includes elements of psychological impact, legal if used in a reasonable and appropriate manner. For example, the interview of two persons who have already been interviewed provides for the impact on interviewees by not only the investigator but also the psychological impact of the participants as a result of the conflict of interests of persons who oppose each other. To a large extent, the presentation of a person for identification is related to the psychological impact on the identifying person, his/her emotional experiences and psychological discomfort.

Moreover, a number of measures applied by the investigator during the pre-trial investigation often show signs of coercion: for example, the involvement of attesting witnesses; the obligation of participants to get informed with the record of the investigative (search) action and to attest the information presented.

Frequently, a specificity of communication in the course of investigative activities is the coercion: objects get involved in legal relations regardless of their will, complying with the provisions of the law and under the threat of certain sanctions, in the context of inequality in communication, restrictions on personal rights and interaction objects' dependence on its actors, due to the nature of the investigative actions [17, pp. 53-53].

During the pre-trial investigation, the tactical techniques of surprise is common, involving the investigator's choice and implementation of a system of techniques and means, providing the enabling environment for collecting of evidentiary information on the basis of their nature and content unexpected for certain participants in investigative (search) actions. Surprise shows highly effective results in practice and involves a system of tactical techniques that ensure suddenness of the investigator's actions in a given investigative situation.

In psychological aspect, surprise is aimed at suddenness for the unscrupulous participant, causing him a state of confusion, breaking the prepared stereotype of behaviour, false answers [18, pp. 209-210].

\section{CONCLUSIONS}

In general, any psychological technique requires thorough training of the investigator, including the check of their compliance with legal and moral standards; evaluation of possible tactical risk and its justification; prediction of the behaviour of the participants in the investigative (search) action; determination of measures to be taken in case of the emergency and the situation spiralling out of control; application of the results obtained.

In other words, the psychological impact is inherent in the investigator's performance and reflects its essence. The application of appropriate measures is subject to their objective necessity, legality and compliance with human rights and freedoms in order to achieve the objectives of criminal proceedings.

Therefore, the psychological description of investigative (search) actions covers objective psychological patterns and individual specificities conveyed during their implementation in the framework 
of cognitive, constructive, communicative, organizational, predictive and verifying operations aimed

\section{REFERENCES}

[1] Kuzmichov, V.S. \& Chornous, Yu.M. (2005), Slidcha diialnist: kharakterystyka ta napriamy udoskonalennia [Investigative activity: characteristics and directions of improvement], Nichlava, Kyiv, Ukraine.

[2] Karpushyna, S.Yu. (2016), Provedennia slidchykh (rozshukovykh) dii [Conducting investigative (search) actions], Extended abstract of candidate's thesis, Kyiv, Ukraine.

[3] Barabash, Oleg Laptiev, Oleksandr Sobchuk, Valentyn Salanda, Ivanna Melnychuk, Yulia and Lishchyna, Valerii (2021), "Comprehensive Methods of Evaluation of Distance Learning System Functioningt", International Journal of Computer Network and Information Security, vol. 13, no. 3, pp. 62-71. DOI: $10.5815 /$ ijcnis.2021.03.06

[4] Ismail Aliyu, A. F. D. Kana and Salisu Aliyu (2020), "Development of Knowledge Graph for University Courses Management", International Journal of Education and Management Engineering, vol. 10, no. 2, pp. 1-10. DOI: $10.5815 /$ ijeme.2020.02.01

[5] Enesi Femi Aminu, Ishaq Oyebisi Oyefolahan and Muhammad Bashir Abdullahi, Muhammadu Tajudeen Salaudeen (2020), "A Review on Ontology Development Methodologies for Developing Ontological Knowledge Representation Systems for various Domains", International Journal of Information Engineering and Electronic Business, vol. 12, no. 2, pp. 28-39. DOI: $10.5815 /$ ijieeb.2020.02.05

[6] Kohutych, I.I. (2019), "On the actualization of the philosophical aspect of the development of the general theory and methodology of criminology", Kryminalistyka i sudova ekspertyza, Criminalistics and Forensics, vol. 64, pp. 35-48. DOI: $10.33994 /$ kndise.2019.64.01

[7] Korystin, Oleksandr and Svyrydiuk, Nataliia (2020), "Methodological principles of risk assessment in law enforcement activity", Nauka i Pravookhorona, vol. 3 (49), pp. 191-198, DOI: 10.36486/np.2020.3(49).19

[8] Korystin, Oleksandr and Svyrydiuk, Nataliia (2021), "Formation of security competences in law enforcement activities", Nauka i Pravookhorona, vol. 1 (51), pp. 191-198, DOI: 10.36486/np.2021.1(51).20 at forensically relevant information handling and at establishing facts of criminal proceedings.

[9] Korystin, O.Y. Svyrydiuk, N.P. Mihus, I.P. Likhovitskyy, Y.O. and Mitina, O.M. (2020), "Money laundering: macroeconomic assessment methods and current trend in Ukraine", Financial and credit activities: problems of theory and practice, vol. 1 (32), pp. 341-350, DOI: 10.18371/fcaptp.v1i32.20086

[10] Tishchenko, V.V. (2003), "Conceptual bases of investigation of mercenary and violent crimes", Extended abstract of Doctor's thesis, Kharkiv, Ukraine.

[11] Danshyn, M.V. (2002), "Classification of ways to conceal crimes in criminology", Extended abstract of candidate's thesis, Kharkiv, Ukraine.

[12] Konovalova, V.E. (1973), Organizatsionnye $i$ psikhologicheskie osnovy deiatelnosti sledovateley [Organizational and psychological foundations of the investigator's activities], RIO MVD USSR, Moskov, Russian.

[13] Halahan, V.I. (2002), Problemy vdoskonalennia kryminalno-protsesualnoi diialnosti orhaniv vnutrishnikh sprav Ukrainy [Problems of improving the criminal procedure of the internal affairs bodies of Ukraine], Nats. akad. vnutr. sprav Ukrainy, Kyiv, Ukraine.

[14] Bernaz, V. \& Neledva, N. (2013), "Regulation of the beginning of pre-trial investigation as a basis of criminal procedure proceedings", Visnyk prokuratury, Bulletin of the prosecutor's office, vol. 1, pp. 62-67.

[15] Medvediev, V.S. (2000), "Psychological aspects of the bodies of internal affairs of Ukraine in ensuring the rights of citizens", Naukovyi visnyk Natsionalnoi akademii vnutrishnikh sprav Ukrainy, Scientific Bulletin of the National Academy of Internal Affairs of Ukraine, vol. 2, pp. 119-130.

[16] Chornous, Yu.M. (2020), "Psychological bases of realization of tactical receptions", Yurydychna psykholohiia, Legal psychology, vol. 1(26), pp. 1322. DOI: $10.33270 / 03202601.13$

[17] Androsiuk, V.H. Kazmirenko, L.I. \& Kondratiev, Ya.Yu. (et al.), Yurydychna psykholohiia [Legal psychology], In Yure, Kyiv, Ukraine.

[18] Chornous, Yu.M. (2017), Kryminalistychne zabezpechennia rozsliduvannia zlochyniv [Forensic support of crime investigation], Nilan-LTD, Vinnytsia, Ukraine. 